\title{
Contribution of ROI Methodology to Romanian Pharmaceutical Industry through E-learning to Improve Employees' Performance
}

\author{
Petruta Blaga, Manuela Rozalia Gabor
}

\author{
"PetruMaior" University of TirguMures \\ NicolaeIorga str, no. 1, 540 088, TirguMures, Mures County, Romania \\ E-mail.petruta.blaga@upm.ro,rozalia.gabor@ea.upm.ro \\ cross $^{\text {ref }}$ http://dx.doi.org/10.5755/j01.ee.29.3.12710
}

\begin{abstract}
The capability of organizations to accumulate and use new knowledge represents a critical factor if they want to comply with the new competitive standards on the market. The need of adaptation to modifications of external environment hastens the pace of evolution and learning. The need to survive on the market requires an increasingly high learning pace from the organizations. The new information and communication technologies fasten the pace of change and increase the need for learning that is subject to an increased information flow. This research aims to measure the impact and the efficiency of elearning training programs on employees within an organization, which is the market leader within the pharmaceutical field. The carried-out research aims to put into practice the theoretical frame of ROI methodology of evaluating the business education programs on human resources in five stages, suggested by J. J. Phillips. The case study is based on using quantitative analysis according to the suggested research methodology. The variables used in the entire research were: feedback and satisfaction, learning and confidence in application, the impact on the organization's business results. The results of the research validate the theoretical data of the surveyed model and are based on the analysis of the data gathering process within the ROI methodology. This work shows only the evaluation stage of assimilating knowledge and competences and the evaluation stage of performance improvement in the participants workplace after attending the e-learning training program. The research results have emphasized higher applicability in practice, in the workplace, in terms of the knowledge acquired by respondents after training, and high efficiency of the e-learning training program, respectively.
\end{abstract}

Keywords: E-Learning; Pharmaceutical Industry; Romania; Feedback From Trainees; Job Impact.

\section{Introduction}

Most managers and human resources specialists consider that in an economic crisis, when most organizations focus on efficiency in spending their budgets and personnel restructuring, investing in human resources (Beardwell \& Claydon, 2007) and providing training programs (Hanczik, 2007) may have significant results.

Therefore, human resources evaluation and taking related action in this respect should be present in every organization (McLean \& Moss, 2003; Harris, 2007; Schreurs, 2006). The importance of evaluating human resources development initiatives within an organization is related to measuring the investment profitability in such kind of projects (Abrudan \& Dodescu, 2010).

The paper emphasizes an evaluation methodology of the human resources training process from the perspective of ROI methodology that can help organizations use the most suitable tools in order to measure the manner in which human resources training programs contribute to the organization's success.

The scientific problem of this research is to put into practice the theoretical frame of ROI (Return on Investment) methodology of evaluating the e-learning training programs for human resources in five stages, suggested by J. J. Phillips, and to validate theoretical data of the surveyed model.

This research aims to measure the impact of some initiatives within human resources on the organization, which is the market leader within the pharmaceutical field, by measuring the efficiency of business education programs on human resources through e-learning. The objective of this research is to provide the required resultsf or the continuation of the logical approach proposed by Kirkpatrick (four stages framework) and Phillips (five stages framework) methodologies.

The research is focused on the analysis of Data collection process within the ROI Methodology:

- Aspects related to measuring the participants feedback on the e-learning training program have already been published (Blaga \& Gabor, 2014), according to the first level of Kirkpatrick and Phillips's ROI methodology.

- This paper presents only the results related to the second and the third stages, the evaluation stage of assimilating knowledge and competencies and the evaluation stage of improving performance in the participants' workplace after attending the e-learning training program. Due to the complexity of this research (Blaga, 2012), this paper shows only the results of the impact of the evaluation stage of the elearning training program on the organization.

- Aspects related to the evaluation stages of assimilating knowledge and competencies and evaluation of performance improvement in the trainees workplace after the e-learning training program (Andronie, 2012) have already been published (Blaga \& Gabor, 2016).

- Evaluation of the impact of the training programs on the 
Petruta Blaga, Manuela Rozalia Gabor. Contribution of ROI Methodology to Romanian Pharmaceutical Industry through...

performance of the organizations from the pharmaceutical sector using the ROI methodology is the object of a paper that is under review within another specialty publication.

Under these circumstances, this research aims to put into practice the theoretical frame of the ROI methodology of evaluating the human resources training programs in five stages (Giziene, Simanaviciene, Palekiene, 2012), suggested by Dr. Jack J. Phillips, who developed D. L. Kirkpatrick's four-level model (Kirkpatrick, 1994, 1998), by adding the fifth level, named ROI, that consists in measuring the investment return of training human resources in organizations (Phillips, 1998, 2003). ROI methodology can help determine the extent to which human resources training programs contribute to an organization's success, while promoting the development of strategic analysis and decision-making capabilities.

This research has been conducted using quantitative analysis according to the suggested research methodology. The practical application is combined with a statistical analysis that validates the theoretical data from the evaluation model used. The subject of the research was the e-learning training program Quality analysis and evaluation methods. The variables used in the research were as follows: feedback and satisfaction, learning and confidence in application, the impact on the organization's business results. Data gathered from questionnaires based on a 5point Likert scale were summarized and analyzed using SPSS software and Excel.

Research strategies used to evaluate the four stages of data collection within the ROI methodology generated a significant volume of data that could be reviewed and analyzed for the purposes of the study.

In 2008, a single case study was conducted in Romania entirely at MedLife, the market leader in the field of private medical services, by ROI Institute Romania, a research, benchmarking and consulting organization that provides workshops, publications and consulting services based on the ROI methodology (ROI Institute, 2009).

In the case study presented in this paper, the learning evaluation led to a series of findings related to participant understanding of how the educational content of the elearning training was conceived and presented, which content determined the acquisition of knowledge and capabilities specific to the program.

As a result of this research that was conducted to evaluate improvement in work performance of participants after the completion of training, one can perceive the great extent to which the specific learning objectives were achieved as they relate to change in employee behavior and conclude that participants significantly applied the knowledge and capabilities to their work that they acquired from the training and that the e-learning training program was highly effective (Dettori, 2015).

The research validates theoretical data from the evaluation model and is based on an analysis of the datagathering process within the ROI Methodology. This work addresses only the evaluation stage of assimilating knowledge and competencies and the evaluation stage of employee performance improvement following e-learning training (Gharibpoor, Sargazi, Aref, 2013). The research results show that respondents significantly applied the knowledge acquired in the training to their work, as well as a high rate of effectiveness of the e-learning training program.

The novel practical element of this research builds on the contributions of researchers in the field who applied the ROI methodology for the first time in Romania (Blaga, 2014) as a tool to evaluate performance improvement on the job in relation to e-learning training programs (Silvestru, Colibaba \& Silvestru, 2007). The pharmaceutical industry was selected (Thoene \& Buszko, 2014) as the research area of focus because of the high number of training programs required in this industry as compared to others.

\section{Literature Review and Conceptual Framework}

According to Donald L. Kirkpatrick there are four levels for evaluating the effectiveness of human resources training programs (Kirkpatrick \& Kirkpatrick, 2005, 2006).

Building on the work of D.L. Kirkpatrick, Jack J. Phillips proposed an evaluation model with five levels(Phillips, 1998, 2003, 2007; Phillips, Phillips, Stone, \& Burkett, 2007), developing the four levels of D.L. Kirkpatrick and adding a fifth level.

1. The first evaluation level, feedback, satisfaction and planned actions, measures the satisfaction degree of participants in relation to the training program. Almost all human resources functions measure programs at this level. Although it is important to measure participant satisfaction with the training program, a good score at this level does not guarantee that participants have learned or if they will put their learning into effect.

2. The second evaluation level, learning and confidence in application, focuses on what participants learned from the training program. This assessment is useful in understanding if participants have acquired new knowledge and/or skills and if they know what they must do for the training program to be considered successful. However, a good score on this measure does not ensure that participants will put their learning into effect.

3. The third evaluation level, application and implementation on the job, requires a data collection process that assesses whether participants in the training program put their learning into effect. The frequency with which skills and knowledge are put into effect is an extremely important element. Moreover, all actions and tasks that participants should take to ensure the success of the training program are evaluated at this level. However, successful implementation does not ensure a positive impact on the organization's business results.

4. The fourth evaluation level, impact on organization's business results, envisages improvement in business results as an outcome of participation in the training program. This level usually includes indicators such as achievements, improved quality, cost savings, improved cycle times and customer satisfaction. Although this evaluation level provides data about the direct impact of the training program on business results, it does not ensure that the costs of the training program are not overly high.

5. The fifth level, ROI, evaluates the monetary benefits of the training program, which means how much the organization has earned, expressed in financial terms, as a result of implementing the training program as compared 
with its costs. The evaluation cycle is never fully complete until the fifth level is evaluated.

\section{Data and Methodology}

The sample used for the survey consists of 45-50 of the organization's 200 total employees, taken from the Quality Management Department, research laboratories, production departments, and distribution, and they were divided into two approximately equal groups with 25 trainees in each. The participants ranged in age from 25 to 60 years. Details of the participant sample are shown in table1.

Table 1

Structure of Sample of e-Learning Program

\begin{tabular}{|c|l|c|}
\hline \multicolumn{2}{|c|}{ Characteristic } & Share in sample \\
\hline Gender & male & $40 \%$ \\
& female & $60 \%$ \\
\hline \multirow{3}{*}{ Age } & $25-34$ years & $36 \%$ \\
& $35-49$ years & $36 \%$ \\
& $50-64$ years & $28 \%$ \\
\hline \multirow{2}{*}{ Education } & University education & $56 \%$ \\
level & Postgraduate education & $36 \%$ \\
& Doctoral education & $8 \%$ \\
\hline \multirow{3}{*}{$\begin{array}{c}\text { Occupational } \\
\text { status }\end{array}$} & Manager & $8 \%$ \\
& Higher educated employee & $72 \%$ \\
& Standard educated & $8 \%$ \\
\hline Position & employee & $28 \%$ \\
within & Management personnel & $72 \%$ \\
organization & Administrative personnel & \\
\hline
\end{tabular}

Through the required training program, the organization aimed to maintain and improve the work quality, knowledge, skills and competencies of its employees in relation to the organization (Marin, 2012), as well as the management of internal quality systems (Nistor, 2007). The training program that was the subject of the research was Quality analysis and evaluation methods (Gazi, Silman \& Birol, 2008).

The training and evaluation period of the participants occurred from January 2012 to July 2013 and was established in line with the priorities of the organization's management during this time period.

For the second evaluation level, learning, the employees participants were trained on the "Methods of quality analysis and assessment", organized in seven modules: Classical techniques and tools for nonnumeric data; Modern techniques and tools; Value analysis. Multi-criteria analysis; Quality planning methods; Technical and qualitative level of products; Economic aspects of quality (1); and Economic aspects of quality (2). Participants were evaluated by a final exam.

The variables used in the complete research were as follows:

-38 items for the first evaluation level, feedback and satisfaction, using the 5-point Likert scale;

-9 tests with ratings from 1 to 10 for the second evaluation level, learning and confidence in application;

-20 items with respect to the third evaluation level, application and implementation on the job, using the 5point Likert scale; Table 2 presented only those items with statistical significance;
-8 items with respect to the fourth evaluation level, impact on organization's business results, using the 5-point Likert scale;

- ROI calculation.

Table 2

Means for Items of the Research

\begin{tabular}{|l|c|}
\hline \multicolumn{1}{|c|}{ Question - Item } & $\begin{array}{c}\text { Achieved } \\
\text { mean }\end{array}$ \\
\hline $\begin{array}{l}\text { 1. Do you use on the job, the knowledge acquired } \\
\text { following the e-learning program related to the quality } \\
\text { analysis and evaluation? }\end{array}$ & 4.84 \\
\hline $\begin{array}{l}\text { 11. To what extent have you the capability to use the } \\
\text { internal communication techniques as a specific tool of the } \\
\text { quality management? }\end{array}$ & 4.95 \\
\hline $\begin{array}{l}\text { 13. How do you describe your capability to take decisions } \\
\text { in due time, in order to increase process efficiency on the } \\
\text { job? }\end{array}$ & 5.16 \\
\hline $\begin{array}{l}\text { 14. How do you describe your capability to take decisions } \\
\text { in due time, in order to increase the process efficacy on } \\
\text { the job? }\end{array}$ & 4.84 \\
\hline $\begin{array}{l}\text { 15. To what extent are you stimulated as employees to } \\
\text { express suggestions and ideas of improving the work on } \\
\text { the job? }\end{array}$ & 4,63 \\
\hline $\begin{array}{l}\text { 16.To what extent your suggestions of continual } \\
\text { improving matter in the decision making, on the job? }\end{array}$ & 4,37 \\
\hline $\begin{array}{l}\text { 17. How do you describe your ability to identify and } \\
\text { gather the main categories of quality costs? }\end{array}$ & 4,42 \\
\hline $\begin{array}{l}\text { 18. To what extent the structure and value of quality costs } \\
\text { interfere in the decision making on the job? }\end{array}$ & 4,47 \\
\hline
\end{tabular}

The first questionnaires were administered to the first group of participants July 6-7, 2012, following completion of their participation in the Quality analysis and evaluation methods training program, developed as distance education using an e-learning format (Ko \& Ko, 2012). Subsequent questionnaires will be administered to the second group of participants who will complete the same training program but in a conventional face-to-face environment.

Organization of the training program into two groups of trainees, with two different training systems, one based on e-learning and the other carried-out using a conventional form of learning (Tureckiova, Veteska\&Valisova, 2008), is the result of a preference expressed by trainees and accepted by the organization's management (Berber, Stangl Susnjar, Slavic \& Baosic, 2014).

Data gathered from questionnaires based on a 5-point Likert scale were summarized and analyzed using SPSS software and Excel to calculate absolute, simple means, calculated average scores, and weighted means as well as Sperman correlation.

\section{Presentation of the Research Results}

After completing the seven modules of the training program, participants were required to fill out eight questionnaires, with the eighth questionnaire being a final Evaluation of knowledge and competence assimilation of participants in the training program. The processing of the data from the eight questionnaires for the entire sample completed this evaluation phase.

The lowest mean score, 8.65, came from the assessment of Module 7_ Economic aspects of quality (2). A possible explanation for this score would be that participants in the sample who have a medical, pharmaceutical or engineering 
Petruta Blaga, Manuela Rozalia Gabor. Contribution of ROI Methodology to Romanian Pharmaceutical Industry through...

educational background found it more difficult to grasp a series of new economic aspects contained in this module compared to trainees with a more general education.

The highest score, 9.46, was achieved for Module 2 Classical techniques and tools for non-numerical data, modern techniques and tools.

Before the final examination, the mean score per trainee for the seven modules covered, as well as the sample mean for the seven modules of the e-learning training program was 9.12. For the entire participant sample, the final mean score was 9.76 with scores ranging from 8.33-10.

In evaluating changes in on-the-job behavior of trainees it appears that all 20 items of the third questionnaire, Evaluation of performance improvement on the job of trainees following the training program, which were measured on a scale from 1 ("I don't know") to 6 ("much more"), registered mean values over 4,indicating a greater on-the-job application of knowledge acquired by trainees following training. Considering that the final objective of training is to put knowledge acquired by employees into immediate practice, the goal when the questionnaires were being developed was to include some questions that could be used to validate the answers given on other questions in the questionnaire.

As an example, one can compare item 13, "How do you describe your capability to take decisions in due time, in order to rise process efficiency on the job?",with item 14,"How do you describe your capability to take decisions in due time, in order to rise process efficacy on the job?" The two scores obtained, 5.16 for item 13 and 4.84for item 14 , do not differ significantly in value, demonstrating that the control question in item 14 effectively validates the results of item 13 .

Item 13 had the highest score, 5.16, and the lowest mean score, 4.32,came from item 19,"To what extent do you survey the technical level and reliability of the products made within the organization?" a score of 4.32 for item 19 indicates that not all the sample respondents are directly involved in the company's production process.

The second questionnaire, Evaluation of performance improvement on the job of trainees following the training program, consists of a single open-ended question at the that invited trainees to provide an answer to: "What elements do you think could lead to increasing the efficiency of the e-learning training program?"

Sixteen percent of participants in the e-learning training program provided the following responses:

- "more explanations to the on-line modules":

- "more examples from practice related to the quality methods".

These two responses confirm responses given by the same respondents on another open-ended question (item 24) from the first questionnaire, Evaluation of feedback/satisfaction of participants in the training program.

Most participants in the e-learning training program indicated that the program was effective (Trocin, 2013; Tahi, Bouarab-Dahmani \& Bouazid, 2014), a conclusion that was also reached after analyzing responses to the 20 questions of the questionnaire that had mean values over 4 , ranging between 4.32 and 5.16 on a scale from 1 to 6 , indicating a high on-the-job application by respondents of the knowledge acquired from the training, and a high effectiveness of the e-learning training program(Um, Kim \& Kym, 2011), respectively.

With respect to the third questionnaire, Evaluation of performance improvement of participants on the job following the training program, a vertical statistical analysis of the questions was performed.

Testing the correlation between item 1, "Do you use the knowledge acquired as a result of the e-learning training program on the job related to the quality analysis and evaluation methods?" and item 11, "To what extent have you the capability to use the internal communication techniques as a specific tool of the quality management?", the result is a direct correlation in the mean values that is statistically significant $(0.672)$, as shown by the data in table 3.

Table 3

Correlation coefficients for items 1 and 11

\begin{tabular}{|c|c|c|c|}
\hline & $\begin{array}{c}\text { Correlaionc } \\
\text { oefficients }\end{array}$ & Item 1 & Item11 \\
\hline $\begin{array}{l}\text { 1. Do you use on the job, the } \\
\text { knowledge acquired following } \\
\text { the e-learning program related to } \\
\text { the quality analysis and } \\
\text { evaluation? }\end{array}$ & $\begin{array}{l}\text { Pearson } \\
\text { Kendall } \\
\text { Spearman }\end{array}$ & $\begin{array}{l}0.726^{* *} \\
0.621^{* *} \\
0.672^{* *}\end{array}$ & \\
\hline $\begin{array}{l}\text { 11. To what extent have you the } \\
\text { capability to use the internal } \\
\text { communication techniques as a } \\
\text { specific tool of the quality } \\
\text { management? }\end{array}$ & $\begin{array}{l}\text { Pearson } \\
\text { Kendall } \\
\text { Spearman }\end{array}$ & & $\begin{array}{l}0.726^{* *} \\
0.621^{* *} \\
0.672^{* *}\end{array}$ \\
\hline
\end{tabular}

The results reveal a high rate of on-the-job application of the knowledge and capabilities acquired from the elearning training program lead to an increased ability of respondents to improve the internal communication skills required to perform well at work and execute quality management procedures.

Analyzing the causal connections among items 13, 14, $15,16,17$ and 18 related to decision-making reveal the following (see Table 4):

- The correlation between items 13 and 14 is a direct mean intensity correlation that is statistically significant (0.615);

- The correlation between items 14 and 17 is a direct high intensity correlation that is statistically significant (0.676);

- The correlation between items 15 and 16 is a direct high intensity correlation that is statistically significant (0.700);

- The correlation between items 15 and 18 is a direct mean intensity correlation that is statistically significant (0.613); and

- The correlation between items 16 and 18 is a direct mean intensity correlation that is statistically significant (0.493).

Table 4

Spearman Coefficients for Items 13-18

\begin{tabular}{|c|c|c|c|c|c|c|}
\hline 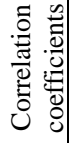 & $\frac{2}{E}$ & $\begin{array}{l} \pm \\
\Xi \\
\Xi\end{array}$ & $\frac{\curvearrowleft}{\stackrel{\Xi}{\Xi}}$ & $\begin{array}{l}0 \\
\stackrel{0}{\Xi} \\
\text { E }\end{array}$ & $\frac{\bar{E}}{\bar{E}}$ & $\frac{\infty}{\Xi}$ \\
\hline
\end{tabular}




\begin{tabular}{|c|c|c|c|c|c|c|c|}
\hline 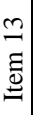 & $\begin{array}{l}P \\
K \\
S\end{array}$ & $\begin{array}{l}1 \\
1 \\
1\end{array}$ & $\begin{array}{c}.498^{*} \\
.602^{* *} \\
.615^{*}\end{array}$ & $\begin{array}{r}\text { NS } \\
.489^{*} \\
.531\end{array}$ & $\begin{array}{l}\text { NS } \\
\text { NS } \\
\text { NS }\end{array}$ & $\begin{array}{l}\text { NS } \\
\text { NS } \\
\text { NS }\end{array}$ & $\begin{array}{l}\text { NS } \\
\text { NS } \\
\text { NS }\end{array}$ \\
\hline $\begin{array}{l} \pm \\
\Xi \\
\Xi \\
\Xi\end{array}$ & $\begin{array}{l}\mathrm{P} \\
\mathrm{K} \\
\mathrm{S}\end{array}$ & $\begin{array}{c}.498^{*} \\
.602^{\text {** }} \\
.615^{\text {** }}\end{array}$ & $\begin{array}{l}1 \\
1 \\
1\end{array}$ & $\begin{array}{r}. \mathrm{NS} \\
.542^{* *} \\
.609^{* *}\end{array}$ & $\begin{array}{l}\text { NS } \\
\text { NS } \\
\text { NS }\end{array}$ & $\begin{array}{l}.795^{\text {** }} \\
.591^{\text {** }} \\
.676^{\text {** }}\end{array}$ & $\begin{array}{l}\text { NS } \\
\text { NS } \\
\text { NS }\end{array}$ \\
\hline 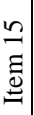 & $\begin{array}{l}\mathrm{P} \\
\mathrm{K} \\
\mathrm{S}\end{array}$ & $\begin{array}{r}\mathrm{NS} \\
.489^{*} \\
.531^{*}\end{array}$ & $\begin{array}{r}\mathrm{NS} \\
.542^{* *} \\
.609^{* *}\end{array}$ & $\begin{array}{l}1 \\
1 \\
1\end{array}$ & $\begin{array}{l}.854^{* *} \\
.655^{* *} \\
.700^{* *}\end{array}$ & $\begin{array}{r}\mathrm{NS} \\
.404^{*} \\
.502^{*}\end{array}$ & $\begin{array}{l}.572^{*} \\
.551^{* *} \\
.613^{* *}\end{array}$ \\
\hline 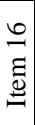 & $\begin{array}{l}\mathrm{P} \\
\mathrm{K} \\
\mathrm{S}\end{array}$ & $\begin{array}{l}\text { NS } \\
\text { NS } \\
\text { NS }\end{array}$ & $\begin{array}{l}. \mathrm{NS} \\
\mathrm{NS} \\
\mathrm{NS}\end{array}$ & $\begin{array}{l}.854^{* *} \\
.655^{\text {** }} \\
.700^{\text {** }}\end{array}$ & $\begin{array}{l}1 \\
1 \\
1\end{array}$ & $\begin{array}{r}\mathrm{NS} \\
.542^{* *} \\
.643^{* *}\end{array}$ & $\begin{array}{r}.493^{*} \\
\text { NS } \\
\text { NS }\end{array}$ \\
\hline 플 & $\begin{array}{l}\mathrm{P} \\
\mathrm{K} \\
\mathrm{S}\end{array}$ & $\begin{array}{l}\text { NS } \\
\text { NS } \\
\text { NS }\end{array}$ & $\begin{array}{l}.795^{* *} \\
.591^{* *} \\
.676^{* *}\end{array}$ & $\begin{array}{r}\mathrm{NS} \\
.404^{*} \\
.502^{*}\end{array}$ & $\begin{array}{r}\mathrm{NS} \\
.542^{* *} \\
.643^{* *}\end{array}$ & $\begin{array}{l}1 \\
1 \\
1\end{array}$ & $\begin{array}{r}\mathrm{NS} \\
.458^{*} \\
.510^{*}\end{array}$ \\
\hline 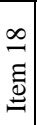 & $\begin{array}{l}\mathrm{P} \\
\mathrm{K} \\
\mathrm{S}\end{array}$ & $\begin{array}{l}\text { NS } \\
\text { NS } \\
\text { NS }\end{array}$ & $\begin{array}{l}\text { NS } \\
\text { NS } \\
\text { NS }\end{array}$ & $\begin{array}{c}.572^{*} \\
.551^{* *} \\
.613^{* *}\end{array}$ & $\begin{array}{r}.493^{*} \\
\mathrm{NS} \\
\mathrm{NS}\end{array}$ & $\begin{array}{r}\mathrm{NS} \\
.458^{*} \\
.510^{*}\end{array}$ & $\begin{array}{l}1 \\
1 \\
1\end{array}$ \\
\hline
\end{tabular}

*. Correlation is significant at the 0.05 level (2-tailed).

**. Correlation is significant at the 0.01 level (2-tailed).

\section{Conclusions}

Improved employee performance resulting from on-thejob training programs cannot be assessed within the theoretical framework of ROI without the evaluation of feedback, satisfaction and planned actions (Blaga \& Gabor, 2014), which was done in accordance with the evaluation steps of Phillips's ROI Methodology, Impact of business results and ROI, an unpublished work of the authors.

This research has been performed using quantitative analysis according to the suggested research methodology. The quantifiable nature of the research data enabled the performance of certain analyses that address the complexity and impact of e-learning training (Shee \& Wang, 2008). Research strategies used to evaluate the four stages of data collection within the ROI methodology generated a significant volume of data that could be reviewed and analyzed for purposes of the study.

Evaluation of learning using the questionnaires for evaluation of assimilation as regards knowledge and competencies of participants in the training program is a significant stage of the ROI methodology as one cannot expect to see any change in participant on-the-job behavior unless one or several learning objectives have been reached as follows: what knowledge has been assimilated, what competencies have been developed or improved, and what attitudes have been changed.

In the study, the evaluation of learning (Gižiene \& Vasiliauskaite, 2007) led to a series of findings related to participant understanding of how the educational content of the e-learning training program has been conceived and presented, which content determined the acquisition of knowledge and abilities specific to the program:

- Participants succeeded, based on educational materials and the e-learning environment, in understanding, applying and explaining the concepts covered in the course modules;

- The level at which information was presented and the time allowed to review the specific concepts, tools and methods facilitated an easy grasp of the knowledge and capabilities;

- Based on the results achieved on the evaluation tests given at the end of each course module, participants improved their knowledge and abilities because of the content they were shown in the e-learning training modules;

The mean scores achieved by trainees on the seven modules of the e-learning training program, as well as the final mean of the entire survey sample lead to the conclusion that participants acquired specific knowledge and abilities from the training, which proves the effectiveness of the $e$ learning training program and demonstrates that e-learning improves employee performance.

The next stage of the data collection process within the ROI methodology was the evaluation of trainees' behavior following the training program based on responses to the questionnaire, Evaluation of performance improvement on the job of participants (Kumpikaite, 2007), which assessed the extent to which trainees change on-the-job behavior as a result of the e-learning training program.

This evaluation stage produced the following findings:

- Trainees successfully understood and used the concepts and methods from the training, demonstrating that sufficient theoretical and practical knowledge had transferred from the training program to change the on-thejob behavior of trainees;

- Trainees significantly improved required skills with good results in situations specific to the surveyed field: ability to identify work situations where the surveyed techniques apply, ability to select the most appropriate tools and techniques that should be used to solve problems, ability to use these techniques, ability to delegate specific responsibilities when using these techniques, ability to use internal communication skills, ability to make timely decisions.

Some trainees provided feedback and suggestions for improvement of the e-learning training program as follows:

- More comprehensive explanations and interactive exercises to facilitate assimilation of knowledge and capabilities;

- Introduction of case studies from practice and of some simulations using e-learning technology (Gatautis, 2008).

As a result of the research conducted to evaluate improvement in work performance of participants after completion of training, one can perceive the great extent to which the specific learning objectives were achieved as they relate to change in employees' behavior, and conclude that participants significantly applied the knowledge and capabilities on the job that they acquired as a result of the training, and that the e-learning training program was highly effective.

The research approach used does have some limitations:

- The research focused on a quantitative approach to e-learning training and did not consider the effectiveness of conventional training at this stage;

- The sampling method used has its own inherent limitations based on the nature of the organization's business, resulting in insufficient data to support a generalization of conclusions; 
Petruta Blaga, Manuela Rozalia Gabor. Contribution of ROI Methodology to Romanian Pharmaceutical Industry through...

- Performing research in another field of activity is restricted because of the difficulty of comparing results obtained from required training and those obtained from other strategies used by human resources organizations;

- Limits on the effectiveness of the analysis of the data collected from responses to questionnaires, given that not all participants in the training program interpreted the questions in the same way.
This paper advocates an evaluation methodology for human resources training that can help organizations use the most appropriate tools to measure the manner in which these training programs contribute to an organization success.

ROI methodology can help to measure the extent to which human resources training programs contribute to organizational success, while enabling the development of strategic analysis and decision-making capabilities.

\section{References}

Abrudan, M., \& Dodescu, A. (2010). The Romanian Training Market in the Field of Human Capital Development: Case Study on the Impact of Universities as Training Programmes Suppliers on Regional Development, 7th International Conference on Intellectual Capital, Knowledge Management and Organisational Learning, Hong Kong, China, 915.

Andronie, I. (2012). E-learning systems performance based on new technologies, 8th International Scientific Conference eLearning and Software for Education Location, Bucharest, Romania, Book Series: eLearning and Software for Education, 2, 184-189.

Beardwell, J., \& Claydon, T. (2007). Human Resources Management. A Contemporary Approach (Fifth Edition), Pearson Education Limited, Harlow, England.

Berber, N., Stangl Susnjar, G., Slavic, A., \& Baosic, M. (2014). Relationship between Corporate Social Responsibility and Human Resource Management - as new management concepts - in Central and Eastern Europe, Inzinerine Ekonomika-Engineering Economics, 25(3), 360-369.

Blaga, P. (2012). E-learning - a new paradigm for education and training of human resources, Communication, Context, Interdisciplinarity, Tirgu-Mures, Romania, 1190-1194.

Blaga, P. (2014). Considerations regarding the ROI measuring methodology of the investment in human resources, Reviewof Management and Economic Engineering, Cluj-Napoca, Romania, 13/1 (51), 11-20.

Blaga, P., \& Gabor, M. R. (2014). Investigating the impact of e-learning as an alternative for business education in pharmaceutical industry in Romania by ROI methodology, Amfiteatru Economic, Bucharest, Romania, 16(37), 902916

Blaga, P., \& Gabor, M. R. (2016). Evaluation of the e-learning program impact over organizations in the Romanian pharmaceutical industry. Indian Journal of Pharmaceutical Education and Research, 50(4), 517-528. https://doi.org/10.5530/ijper.50.4.3

Dettori, G. (2015). Online and hybrid learning design fundamentals. British Journal of Educational Technology, 46(4), E16-E17. https://doi.org/10.1111/bjet.12308_2

Gatautis, R. (2008). The Impact of ICT on Public and Private Sectors in Lithuania. Inzinerine Ekonomika-Engineering Economics, 59(4), 18-28.

Gazi, Z. A., Silman, F., \& Birol, C. (2008). TQM implementation in the Distance Education Institute: A case of North Cyprus, Egitim Arastirmalari-Eurasian Journal Of Educational Research, 8(31), 35-54.

Gharibpoor, M., Sargazi, S., \& Aref, M. (2013). Efficiency evaluation of e-learning compared to traditional education in human resource development (Case Study: Small and medium enterprises in Shiraz), IEEE, 7th International Conference on E-Commerce in Developing Countries: with focus on E-Security (Ecdc).

Gheorghe, M., Ignatov, M. S., \& Funar, P. S. (2011). E - learning. An Innovating Concept in Human Resources Training, Management of Technological Changes, Alexandroupolis, Greece, Book 2, 349-352.

Giziene, V., \& Vasiliauskaite, A. (2007). Evaluation Models of Investments to Education: Application Peculiarities, Inzinerine Ekonomika-Engineering Economics, 52(2), 50-58.

Giziene, V., Simanaviciene, Z., \& Palekiene, O. (2012). Evaluation of Investment in Human Capital Economical Effectiveness. Inzinerine Ekonomika-Engineering Economics, 23 (2), 106-116. https://doi.org/10.5755/j01.ee.23.2.1541

Hanczik, Z. (2007). Training, improvement tool of employee performances, Financial Week, Labour market, Adecco Timisoara, www.sfin.ro/articol_8897/training-ul_instrument_de_imbunatatire_a_performantelor_angajatilor.html

Harris, K. J. (2007). Calculating ROI for training in the lodging industry: Where is the bottom line?, Hospitality Management 26, 485-498. https://doi.org/10.1016/j.ijhm.2005.12.001 
Kirkpatrick, D. L. (1994). Evaluating Training Programs: The Four Levels. San Francisco: Berrett Koehler.

Kirkpatrick, D. L. (1998). Evaluating training programs: The four levels (2nd ed.). San Francisco, CA: Berrett-Koehler Publishers.

Kirkpatrick, D. L., \& Kirkpatrick, J. D. (2005). Transfering learning to behavior: Using the four levels to improve performance. San Francisco, CA: Berrett-Koehler Publishers.

Kirkpatrick, D. L., \& Kirkpatrick, J. D. (2006). Evaluating training programs: The four levels (3rd ed.). San Francisco, CA: Berrett-Koehler Publishers.

Ko, C. P., \& Ko, C. C. (2012). The Relationship of Training Quality in E-learning and Organizational Commitment to Organizational Performance in the Taiwan Service Industry. International Conference on Future Computer Supported Education, South Korea, Book Series: IERI Procedia, 2, 821-827. https://doi.org/10.1016/j.ieri.2012.06.177

Kumpikaite, V. (2007). Human Resource Training Evaluation. Inzinerine Ekonomika-Engineering Economics, 55 (5), 29-33.

Marin, S. M. (2012). Change and innovation in the educational policies and strategies for human resources development, Cyprus International Conference on Educational Research (CY-ICER), Book Series: Procedia Social and Behavioral Sciences, 47, 1662-1667.

McLean, S., \& Moss, G. (2003). They're happy, but did they make a difference? Applying Kirkpatrick's framework to the evaluation of a national leadership program, The Canadian Journal of Program Evaluation, 18(1), 1-23.

Nistor, R. (2007). From Quality to Total QualityManagementul, Editura Alma Mater, Cluj-Napoca, Romania.

Phillips, J. J. (1998). The return-on-investment (ROI) process: Issues and trends. Educational Technology, 38(4), 7-14.

Phillips, J. J. (2003). Return On Investment in Training and Performance Improvement Programs (Second Edition). Elsevier Science Butterworth-Heinemann, Burlington, MA, USA.

Phillips, J. J. (2007). Measuring ROI: The Process, Current Issues, and Trends, ROI Institute, www.roiinstitute.net

Phillips, P. P., Phillips, J. J., Stone, D. R., \& Burkett, H. (2007), The ROI Fieldbook: Strategies for Implementing ROI in HR.

ROI Institute, Inc. TM (2009). Certification in the ROI Methodology. The Complete Impact Measurement Certification System, http://media.roiinstitute.net/pdf/certification/Certification_Overview.pdf

Shee, D.Y., \& Wang, Y. S. (2008). Multi-criteria evaluation of the web-based e-learning system: A methodology based on learner satisfaction and its applications, Computers\& Education, 50(3), 894-905. https://doi.org/10.1016/j.compedu.2006.09.005

Schreurs, J. (2006). EFQM and Kirkpatrick in a Framework for Evaluation of E-learning, Proceedings of the WorldConference on E-Learning in Corporate, Government, Healthcare, and Higher Education, E-Learn 2006, Hawaii, USA, 1780-1785.

Silvestru, C., Colibaba, D. S., \& Silvestru, D. S. (2007). The development of the e-learning platforms in the new economy for a better training of the human resources, Economic Computation and Economic Cybernetics Studies And Research, Bucharest, Romania, 41(1/2), 231-238.

Tahi, R., Bouarab-Dahmani, F., \& Bouazid, T. (2014). E-Learning Advantages and Disadvantages Through an Experimentation, 13th European Conference on e-Learning (ECEL), Copenhagen, Denmark, Book Series: Proceedings on the European Conference of e-Learning, 520-526.

Thoene, M. A., \&Buszko, A. (2014). Quantitative Model of Tacit Knowledge Estimation for Pharmaceutical Industry, Inzinerine Ekonomika-Engineering Economics, 25(1), 40-46.

Trocin, A. (2013). Human resources in back office e-learning services. Current trends,9th International Conference eLearning and Software for Education, Bucharest, Romania, Book Series: eLearning and Software for Education, 432-435.

Tureckiova, M., Veteska, J., \&Valisova, A. (2008). Blended Learning as a Means to Differentiate and Optimise Corporate Training, 7th European Conference on e-Learning, Cyprus, 2, 599-606.

Um, H., Kim, M. S., \& Kym, H. G. (2011). A Study on the Organizational Context for an Individual e-Learning Performance, Information-An International Interdisciplinary Journal, 14 (2), 433-441.

The article has been reviewed.

Received in July, 2015; accepted in June, 2018. 